\title{
Competing transformations of 2-cyanoacetanilides in reactions with derivatives of ethoxymethylenemalonic acid
}

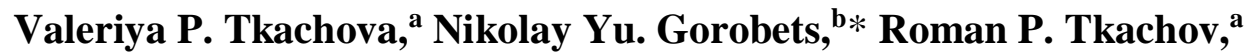 \\ Vladimir I. Musatov, ${ }^{\text {b and Vladimir D. Dyachenko }}{ }^{a}$ \\ aTaras Shevchenko Luhansk National University,Oboronna Str. 2, Luhansk 91011, Ukraine \\ ${ }^{b}$ Department of Chemistry of Heterocyclic Compounds, SSI 'Institute for Single Crystals' \\ of National Academy of Science of Ukraine, Lenin Ave 60, Kharkiv 61001, Ukraine \\ E-mail: gorobets@isc.kharkov.com
}

DOI: $\underline{\text { http://dx.doi.org/10.3998/ark.5550190.0013.635 }}$

\begin{abstract}
Ethoxymethylenemalonodinitrile $\mathbf{1 B}$ and ethyl ethoxymethylenecyanoacetate $\mathbf{1 C}$ in cyclocondensations with 2-cyanoacetanilides $\mathbf{2}$ behave as a three-carbon fragment transfer reagent to afford the corresponding 5-cyano- and 5-ethoxycarbonyl-6-amino-1-aryl-3cyanopyridin-2(1H)-one derivatives 7B and 8C. One carbon transfer described earlier for such reactions with a use of diethyl 2-(ethoxymethylene)malonate $\mathbf{1 A}$ was observed only as a side process in the case of $\mathbf{1 C}$ leading to 2-amino-5-cyano-6-oxo- $N, 1$-diaryl-1,6-dihydropyridine-3carboxamides.
\end{abstract}

Keywords: Cyanoacetanilides, 2-pyridone, ethoxymethylenemalonodinitrile, ethyl ethoxymethylenecyanoacetate, diethyl ethoxymethylenemalonate, conjugative addition

\section{Introduction}

The pyridine ring is fundamental heterocyclic fragment of naturally occurring biomolecules and synthetic compounds. Within several last decades, many affords have been made to design novel synthetic approaches for pyridine ${ }^{1}$ and 2-pyridone ${ }^{2}$ derivatives, mostly small and drug-like molecules. Pharmaceutical properties of $\mathrm{N}$-aryl-2-pyridone derivatives can be illustrated by several examples of bioactive compounds. Among them pirfenidone (Figure 1) has antiphlogistic properties $^{3}$ that are useful at conditions of different inflammatory states ${ }^{4}$. A 3-cyano-2-pyridone derivative, INDOPY-1, has been recently discovered as a human immunodeficiency virus type-1 reverse transcriptase inhibitor ${ }^{5}$ and patented for treatment of HIV-1 and other viral infections. ${ }^{6}$ Another 3-cyano-2-pyridone, milrinone, is a long term known inotropic drug, which is applied 
for treatment of heart failure. ${ }^{7,8}$ Finally, a small alkaloid, ricinine, has been isolated from a toxic plant, castor oil bean (Ricinus communis), and it is suggested as a putative memory-enhancor. ${ }^{9}$<smiles>Cc1ccc(=O)n(-c2ccccc2)c1</smiles>

Pirfenidone<smiles>Cn1c2ccccc2c2c1cc(C#N)c(=O)n2-c1ccc([N+](=O)[O-])cc1</smiles>

INDOPY-1<smiles>Cc1[nH]c(=O)c(C#N)cc1-c1ccncc1</smiles>

Milrinone<smiles>COc1ccn(C)c(=O)c1C#N</smiles>

Ricinine

Figure 1. Biologically active 2-pyridone derivatives.

In our earlier publication series, we have demonstrated synthetic potential of malonic acid ethoxymethylene derivatives in the reactions with thiocyanoacetamide ${ }^{10}$ and monothiomalonamides ${ }^{11}$ leading to different $1 H$-pyridin-2-one derivatives under strong basic conditions (EtONa/EtOH). Many other applications of such highly functionalized alkoxyethylenes for the synthesis of different heterocycles have been also published in the literature. ${ }^{12}$ On the other hand, cyanoacetamides bearing variable diversity point ${ }^{13}$ in the amide group are also described to be used in the 2-pyridone ring synthesis. ${ }^{14}$ Though the reactions between the derivatives of ethoxymethylenemalonic acid and $N$-substituted reminded unknown in the literature until recently.

In our recent report ${ }^{15}$ we have described the reaction of diethyl ethoxymethylenemalonate (DEEMM) 1A with cyanoacetanilides 2. This interaction was shown to give $N$,1-diarylsubstituted pyridone-3-carboxamides $\mathbf{3}$ instead of the expected ethyl 1-arylpyridone-3carboxylates 4 (Scheme 1), which also was formed in a small amount. The application of lower loading of sodium ethoxide ( 0.5 equiv) favored the formation of an open chain intermediate 5 . Thus, DEEMM 1A reacted as a one carbon moiety supplier that links two $\mathrm{CH}$-acids (2) by the methyne bridge, whereas its ability to act as a three-carbon transfer synthon in the formation of the pyridone $\mathbf{4}$ appeared to be quite restricted.

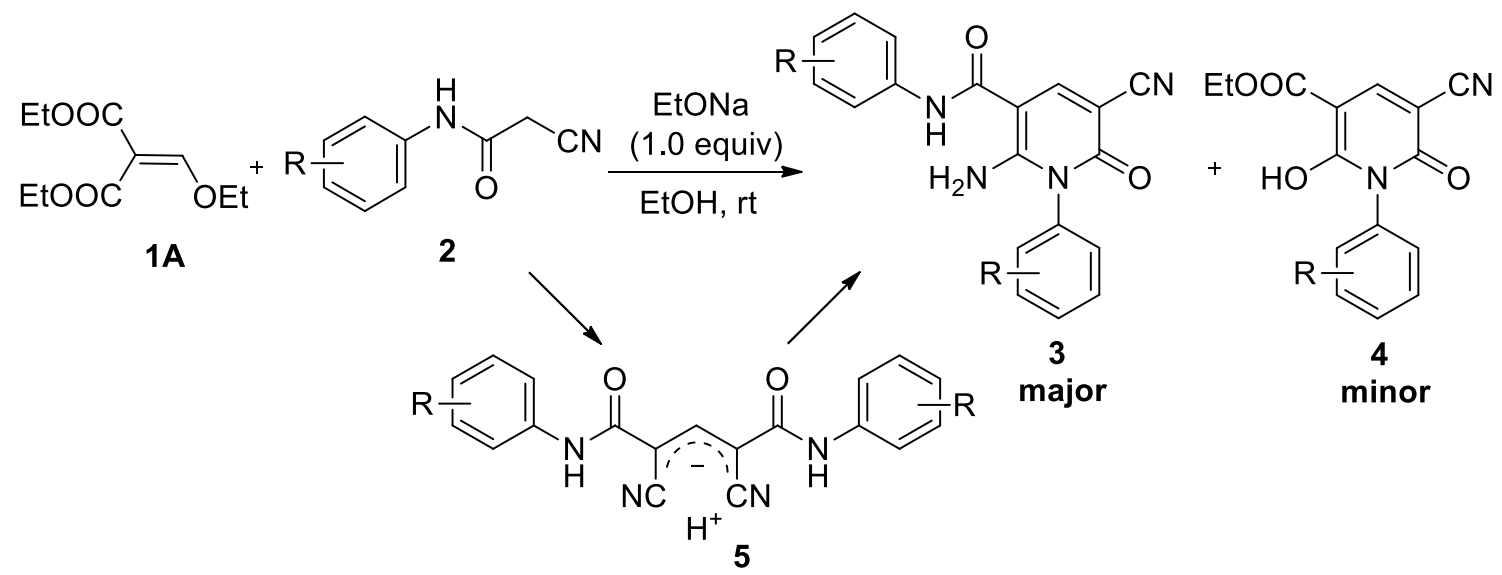

\section{Scheme 1}


Hereby we aimed to compare the behavior of different derivatives of ethoxymethylenemalonic acid bearing cyano and ethyl carboxylate groups in their reactions with cyanoacetanilides 2a-g. For this purpose we use here ethoxymethylenemalonodinitrile $\mathbf{1 B}$ and ethyl ethoxymethylenecyanoacetate $\mathbf{1 C}$ (Figure 2 ).

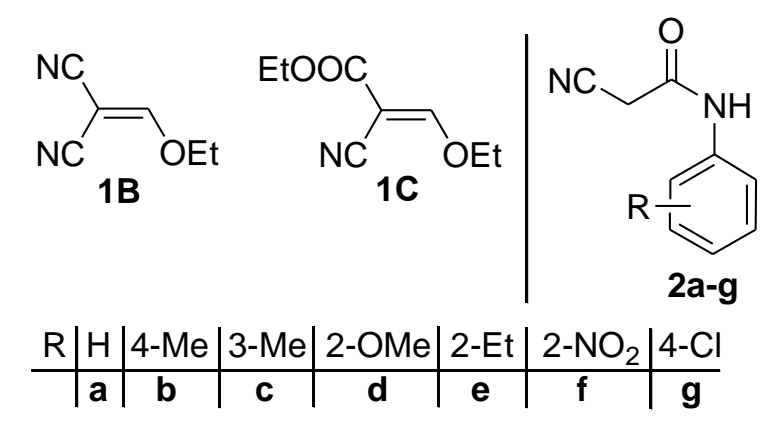

Figure 2. Selected starting compounds.

\section{Results and Discussion}

Application of the previously described conditions (Scheme 1) for the reaction of ethoxymethylenemalonodinitrile $\mathbf{1 B}$ with cyanoacetanilides $\mathbf{2 a - g}$ (Scheme 2) resulted in formation of the expected 6-amino-1-aryl-2-oxo-1,2-dihydropyridine-3,5-dicarbonitriles 7Ba$\mathbf{B g}^{16}$ formed as precipitates in good isolated yields after recrystallization (Table 1). The use of less amounts of EtONa resulted in significantly lower product yields.

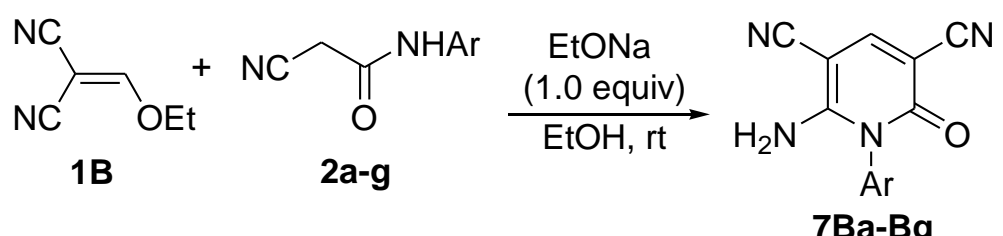

\section{Scheme 2}

The isolated yields for the crude pyridones 7 were near to quantitative. However the crude products required purification from the sodium ethoxide remains and the isolated yields for the pure products $\mathbf{7 B a - B g}$ (Table 1) obtained by recrystallization varied between $55-78 \%$.

The spectral and analytical data for these novel products $\mathbf{7 B a - B g}$ fully corresponds to the drawn structure. In the IR spectra of these compounds two characteristic bands of the cyano groups are observed as well as bands corresponding to $\mathrm{NH}_{2}$ and $\mathrm{C}=\mathrm{O}$ group vibrations. The ${ }^{1} \mathrm{H}$ and ${ }^{13} \mathrm{C}$ NMR spectral data are also in accordance with the suggested structure. 
Thus in contrast to DEEMM 1A (Scheme 1) which supplies one carbon methane moiety to the final pyridone ring, ethoxymethylenemalonodinitrile $\mathbf{1 B}$ works as three carbon transfer reagent providing the efficient synthesis of dicyanopyridones $\mathbf{7 B}$.

Table 1. Isolated yields of the synthesized compounds $7 \mathbf{B a}-\mathbf{B g}$ and $\mathbf{8 C a}-\mathbf{C g}$

\begin{tabular}{llll}
\hline & $\mathrm{R}$ & $\begin{array}{l}\text { Isolated yields, \% } \\
\text { Product 7Ba-Bg }\end{array}$ & $\begin{array}{l}\text { Isolated yields, \% } \\
\text { Product } \mathbf{8 C a - C g}\end{array}$ \\
\hline a & $\mathrm{H}$ & 55 & 53 \\
b & $p-\mathrm{Me}$ & 60 & 62 \\
c & $m-\mathrm{Me}$ & 78 & 65 \\
d & $o-\mathrm{OMe}$ & 75 & 55 \\
e & $o-\mathrm{Et}$ & 55 & 68 \\
f & $o-\mathrm{NO}_{2}$ & 61 & 60 \\
g & $p-\mathrm{Cl}$ & 75 & 74 \\
\hline
\end{tabular}

Ethyl ethoxymethylenecyanoacetate $\mathbf{1 C}$ contains the cyano and ethyl carboxylate groups and both of them may participate in the final stage of the pyridone ring closure during the reaction with cyanoacetanilides $\mathbf{2 a - g}$. Thus formation of products $\mathbf{8}$ and $\mathbf{9}$ can be expected. In addition the competitive process of the one carbon moiety transfer with formation of $N, 1$-diarylpyridines $\mathbf{3}$ may also complicate the reaction (Scheme 1). Thus, three directions for the transformation of the polifunctionalized building-block 1C may be possible. Our experiments has demonstrated (Scheme 3) that the reaction between 1C and nitriles 2a-g leads to 2-aminopyridine-3carboxylate derivatives $\mathbf{8 C a -} \mathbf{C g}^{16}$ formed as main products and isolated in average yields after recyclization (Table 1 ).

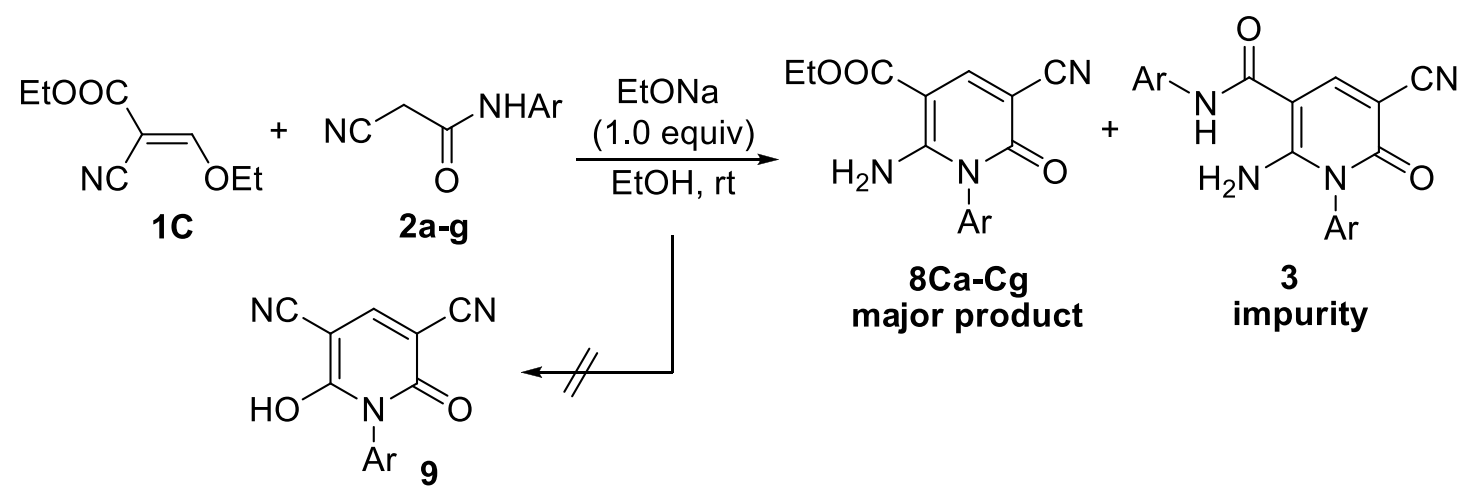

\section{Scheme 3}

The formation of the previously described $N, 1$-diarylpyridines $3^{15}$ was detected by LC/MS and ${ }^{1} \mathrm{H}$ NMR of the crude reaction products in very small amounts $(\sim 4 \%)$. Thus this interaction leads to two products: the main product $\mathbf{8}$ and by-product $\mathbf{3}$. At the same time, the possible products of the ring closure by the ethyl carboxylate group 9 were not detected. 
Taking into account the results obtained (Schemes 1-3) one can suggest the following mechanistic concept for the reactivity of the ethoxymethylene derivatives 1A-C with cyanoacetanilides 2 . It can be concluded the intramolecular nucleophilic addition of the amide $\mathrm{NH}$ to the cyano group is more favorable than the intramolecular acylation of the amide nitrogen by the ethyl carboxylate group. From this point of view, it is clear why the reaction of the dinitrile 1B (Scheme 2) proceeds easily giving one product 7 , whereas in the case of the diester $1 \mathrm{~A}$ the intermolecular acylation (with formation of $\mathbf{4}$, Scheme 1) represents only a side transformation, while the mainstream reaction appears to be the one carbon transfer leading to diaryl derivatives 3 . When the cyano and ethyl carboxylate groups compete in one reaction (Scheme 3), the main product $\mathbf{8}$ is formed also due to the ring closure involving the cyano group, and the one carbon transfer becomes the side process in this case. The formation of diaryl derivatives 3 may be accomplished via two possible mechanisms. ${ }^{15}$ The first (Scheme 4) suggests initial transfer of the ethoxymethylene moiety from $\mathbf{1 C}$ onto the active cyanomethylene compound 2 giving ethoxymethylene derivative 11, which then reacts with another molecule 2 resulting in pyridone $\mathbf{3}$. This process should be slower than the conjugate addition of the methylene active nitrile $\mathbf{2}$ to $\mathbf{1 C}$ followed by formation of the main product $\mathbf{8}$ via an open chain intermediate $(\boldsymbol{E})$-10. Alternatively, due to the hindered intermolecular acylation in the intermediate $(\boldsymbol{Z}) \mathbf{- 1 0}$, the diaryl derivative $\mathbf{3}$ could be formed via Michael addition of the active nitrile $\mathbf{2}$ to $(Z)-\mathbf{1 0}$ followed by retro-Michael addition (Scheme 4).

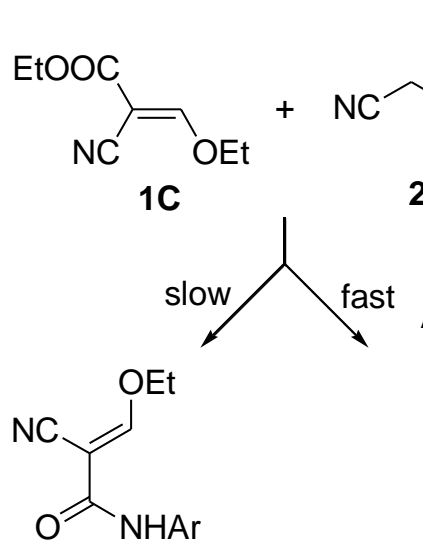

11<smiles>CCNC(=O)c1cc(C#N)c(=O)n([Ga])c1N</smiles>

3<smiles>N#C[Ge]C(=O)N[Ga]</smiles>
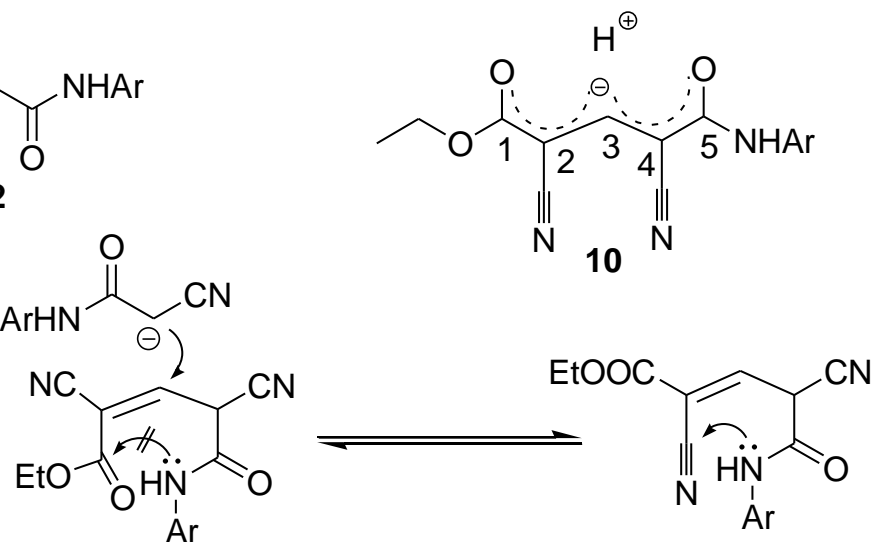

(Z)-10

(E)-10<smiles>CCOC(=O)c1cc(C#N)c(=O)n([Ga])c1N</smiles>

retro Michael addition

\section{Scheme 4}


We suppose that structure of the intermediate $\mathbf{1 0}$ is similar to the structure of the linear product 5 that was described earlier. ${ }^{15}$ In the strong basic medium all five carbon atoms of anion $\mathbf{1 0}$ have $\mathrm{sp}^{2}$-hybridization (Scheme 4). The excessive negative charge in the intermediate $\mathbf{1 0}$ is probably efficiently dispelled between the electron acceptor groups in the molecule that should form a plane structure. In the case of the intramolecular nucleophilic addition of the amide NH to the cyano group (intermediate $(\boldsymbol{E})$-10) the structure remains planar during the ring closure process. On the other hand, the cyclization of $(\boldsymbol{Z})-\mathbf{1 0}$ involving COOEt group requires violating of the planar structure and breaking the conjugation. We assume that this can be the reason why the ethyl carboxy group unwillingly reacts with the amide nitrogen and loses the competition in favor of the cyano group.

It should be pointed that when such conjugation is absent in the acyclic intermediate $\mathbf{1 3}$ the cyclization into the pyridone ring proceeds by the reaction of the amide nitrogen and COOEt group avoiding the neighboring nitrile function. Thus the ethylene derivatives $\mathbf{1 1}$ were described $^{17}$ to react with cyanoacetamide 12 under similar conditions giving the products of intramolecular acylation of the amide nitrogen 14 (Scheme 5).

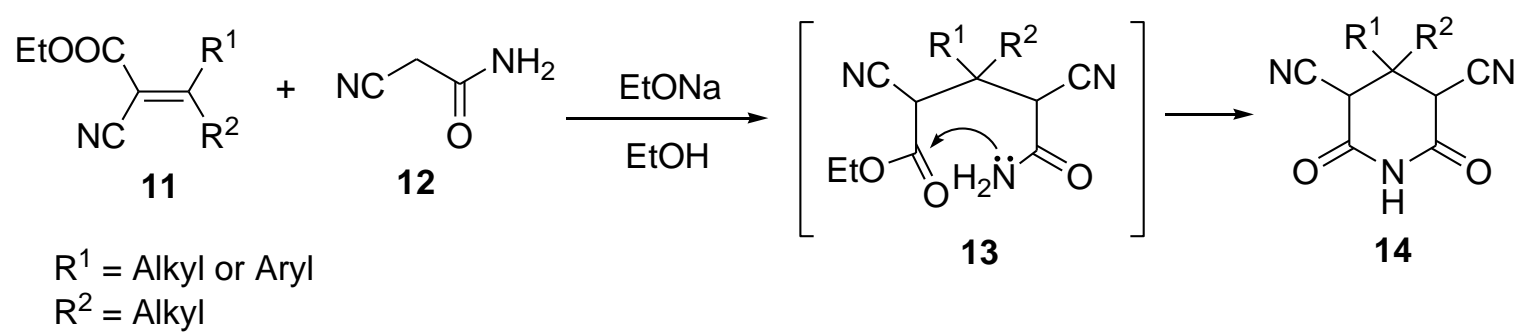

\section{Scheme 5}

In the case of intermediates of type $\mathbf{1 3}$ where the conjugation is absent the ring closure with participation of the COOEt group proceeds smoothly. A number of similar cyclizations where ethyl carboxylate group forms pyridone ring with (thio)amide function are also described using different reaction conditions. ${ }^{18}$ However beside our rationalization of these facts there also can be other specific rezones for such alternation of the relative reactivity.

\section{Conclusions}

The competing pathways for the transformations of 2-cyanoacetanilides in the reactions with derivatives of ethoxymethylenemalonic acid 1A-B are outlined on the Scheme 6. It can be concluded that in such reaction the cyano group readily reacts with the amide nitrogen to form the 6-aminopyrid-2-one cycle. Vice-versa, the ethyl carboxylate function unwillingly participates in the ring closure. This is in contrast to the analogous hydrogenated derivatives where the opposite relative reactivity of these groups is observed (Scheme 5). These facts are rationalized 
on the bases of our suggested reaction mechanism (Scheme 4) where the cyclization of the intermediate 10 with participation of COOEt group requires unfavorable violation of the conjugated planar structure $\mathbf{1 0}$ while the conjugative addition to the cyano group can be accomplished without such steric hindrance.

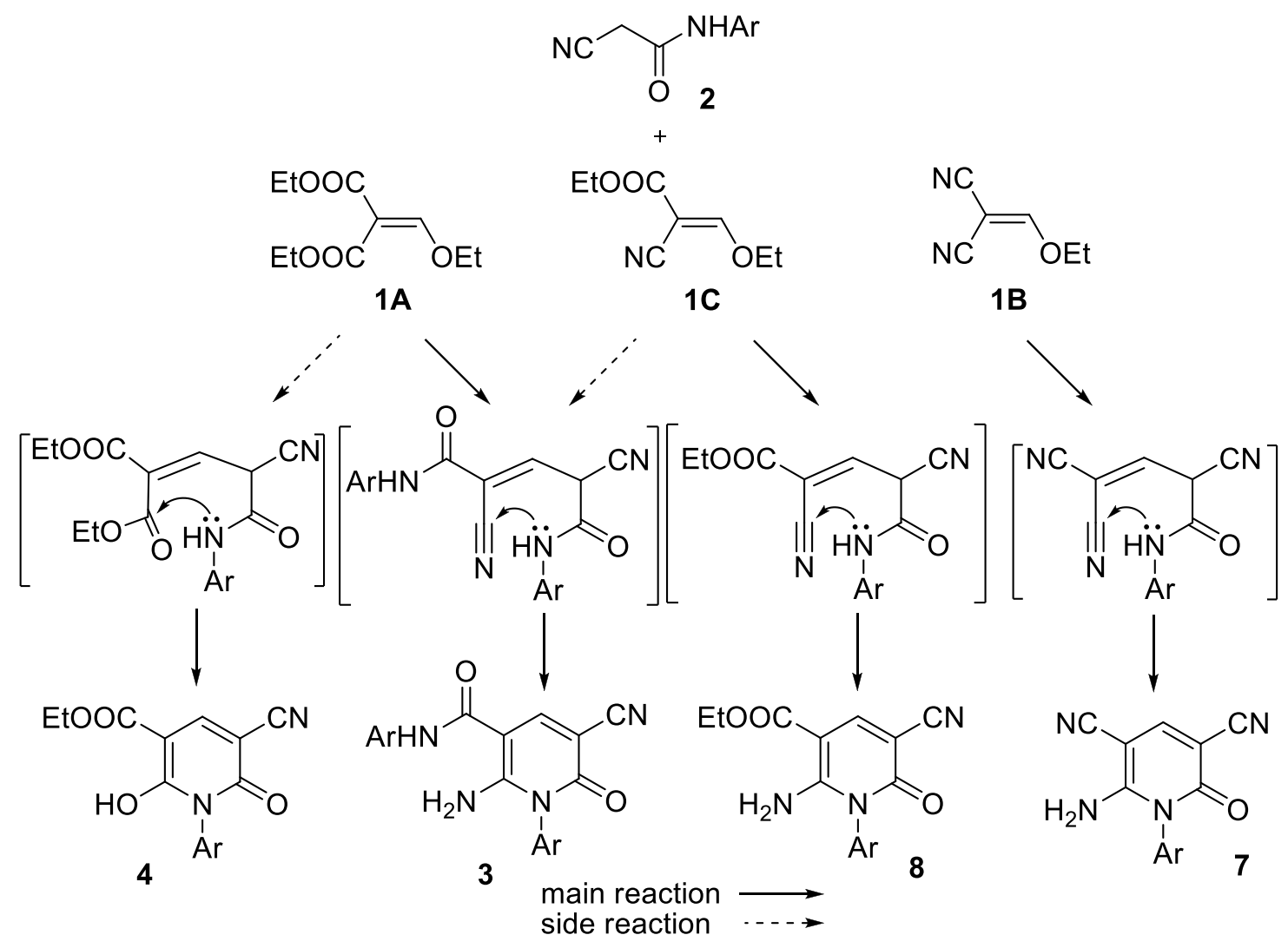

\section{Scheme 6}

Finally, the dicyano derivative $\mathbf{1 B}$ in the reactions with cyanoacetanilides $\mathbf{2}$ acts as an efficient three carbon transfer reagent in the formation of compounds 7 . The mono cyano derivative $\mathbf{1 C}$ acts also in this way giving the main products $\mathbf{8}$, but already demonstrates its weak ability to react as one carbon moiety supplier giving small amounts of compounds $\mathbf{3}$. This pathway becomes the major one when the both cyano groups are substituted by ethyl carboxylate functions in $\mathbf{1 A}$, and this reagent unwillingly gives the corresponding three carbon transfer products 4 (Scheme 7). It should be pointed that the propensity of the ethoxymethylene derivatives to act as one carbon linkers of two $\mathrm{CH}$-acids has not been discussed previously in the literature, ${ }^{19}$ except our preliminary work. ${ }^{15}$ 
The increase of ability to act as one carbon linker reagent

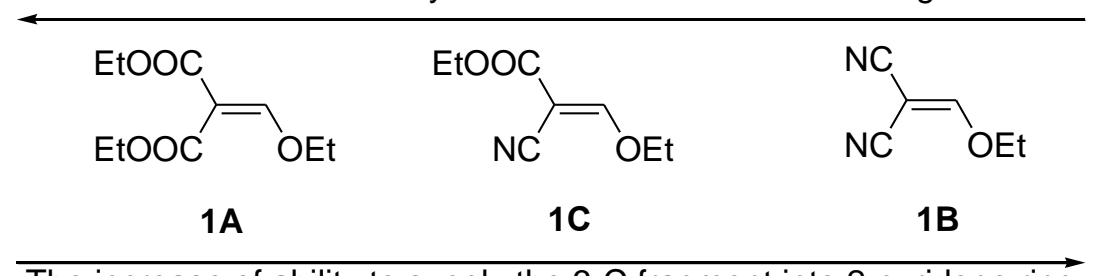

The increase of ability to supply the $3-\mathrm{C}$ fragment into 2 -pyridone ring

\section{Scheme 7}

The ethoxymethylenemalonic acid derivatives are small poly-functional reactive building blocks and in this work their competing transformations with 2-cyanoacetanilides leading to different highly substituted 2-pyridones have been elucidated and rationalized.

\section{Experimental Section}

General. The IR spectra were recorded on a FIR «Spectrum One» (PerkinElmer) in $\mathrm{KBr}$. Melting points were determined on a Koeffler apparatus. ${ }^{1} \mathrm{H}$ and ${ }^{13} \mathrm{C}$ NMR spectra were recorded on Varian Mercury VX-200 and Bruker Avance DRX 500 spectrometers in DMSO- $d_{6}$ with TMS as an external standard. LC/MS data were recorded using chromatography/mass spectrometric system "Agilent 1100 Series" equipped with a diode-matrix and mass selective detector "Agilent LC/MSD SL" with Zorbax SB-C18, $1.8 \mu \mathrm{m}, 4.6 \mathrm{~mm} \times 15 \mathrm{~mm}$ column using eluents: A, acetonitrile/water (95:5), 0.1\% TFA; B, water (0.1\% of TFA) and eluent flow: $3 \mathrm{~mL} / \mathrm{sec}$. Volume of the injected sample was $1 \mu \mathrm{L}$. UV detectors were operated at 215, 254 and $265 \mathrm{~nm}$. Chemical ionization under atmospheric pressure was used in MS detector. Ionization mode: simultaneous scanning of positive and negative ions in the mass range of $80-1000 \mathrm{~m} / \mathrm{z}$. TLC was performed on Silufol UV-254 plates with eluent system: acetone-hexane (3:5), visualization: UV light, iodine vapors.

Preparation of compounds 7 and 8. Sodium $(0.005 \mathrm{~mol})$ was dissolved in absolute EtOH, to this solution the appropriate $\mathrm{CH}$-acid $\mathbf{2}(\mathbf{a}-\mathbf{g})(0.005 \mathrm{~mol})$ was added and stirred for $5 \mathrm{~min}$ at $\mathrm{rt}$. Ethoxymethylenes $\mathbf{1 B}$ or $\mathbf{1 C}(0.005 \mathrm{~mol})$ was added to this mixture and stirred for $1 \mathrm{~h}$ at $\mathrm{rt}$. The precipitate $\mathbf{7}$ or $\mathbf{8}$ correspondingly was filtered off and washed with ethanol and hexane, crystallized from $\mathrm{AcOH}, \mathrm{BuOH}, \mathrm{MeOH}$ or $\mathrm{DMF}$.

6-Amino-2-oxo-1-phenyl-1,2-dihydropyridine-3,5-dicarbonitrile (7Ba). Yield 55\%; pale yellow powder (from MeOH); mp $235^{\circ} \mathrm{C}$. IR (KBr) cm${ }^{-1}: 3375,3293,3214\left(\mathrm{NH}_{2}\right), 2227,2209$ $(\mathrm{C} \equiv \mathrm{N}), 1693(\mathrm{C}=\mathrm{O}) . \mathrm{LC} / \mathrm{MS}, m / z(\%): 237.0(100)[\mathrm{M}+1]^{+} .{ }^{1} \mathrm{H}$ NMR (500 MHz, DMSO-d6) $\delta$ $7.15\left(\mathrm{~d}, J=7.6 \mathrm{~Hz}, 2 \mathrm{H}, \mathrm{H}_{\mathrm{Ar}}\right), 7.40\left(\mathrm{t}, J=6.9 \mathrm{~Hz}, 1 \mathrm{H}, \mathrm{H}_{\mathrm{Ar}}\right), 7.48\left(\mathrm{t}, J=7.6 \mathrm{~Hz}, 2 \mathrm{H}, \mathrm{H}_{\mathrm{Ar}}\right), 7.74(\mathrm{~s}$, $\left.1 \mathrm{H}, \mathrm{C}^{4} \mathrm{H}\right)$, the signal of $\mathrm{NH}_{2}$ was not observed presumably due to the fast deuteron-exchange. 
${ }^{13} \mathrm{C}$ NMR $\left(50 \mathrm{MHz}, \mathrm{DMSO}-d_{6}\right) \delta 77.85,79.44,118.97,119.59,128.02,128.69,129.60,129.94$, 136.84, 147.79, 162.05. Anal. Calcd for $\mathrm{C}_{13} \mathrm{H}_{8} \mathrm{~N}_{4} \mathrm{O}$ : C, 66.1; H, 3.4; N, 23.7. Found: C, 66.4; $\mathrm{H}$, 3.8; N, 23.9. $M=236,23$.

6-Amino-2-oxo-1-p-tolyl-1,2-dihydropyridine-3,5-dicarbonitrile (7Bb). Yield 60\%; pale yellow powder (from AcOH); mp 314-315 ${ }^{\circ} \mathrm{C}$. IR (KBr) cm ${ }^{-1}: 3395,3299\left(\mathrm{NH}_{2}\right), 2220,2217$ $(\mathrm{C} \equiv \mathrm{N}), 1678(\mathrm{C}=\mathrm{O}) . \mathrm{LC} / \mathrm{MS}, \mathrm{m} / z(\%): 249.2(100)[\mathrm{M}-1]^{-} .{ }^{1} \mathrm{H}$ NMR (500 MHz, DMSO-d $) \delta$ $2.39\left(\mathrm{~s}, 3 \mathrm{H}, \mathrm{CH}_{3}\right), 7.21\left(\mathrm{~d}, J=8.0 \mathrm{~Hz}, 2 \mathrm{H}, \mathrm{H}_{\mathrm{Ar}}\right), 7.38\left(\mathrm{~d}, J=7.9 \mathrm{~Hz}, 2 \mathrm{H}, \mathrm{H}_{\mathrm{Ar}}\right), 8.29\left(\mathrm{~s}, 1 \mathrm{H}, \mathrm{C}^{4} \mathrm{H}\right)$, the signal of $\mathrm{NH}_{2}$ was not observed presumably due to the fast deuteron-exchange. ${ }^{13} \mathrm{C} \mathrm{NMR}(50$ MHz, DMSO- $\left.d_{6}\right) \delta 21.38,74.02,87.67,116.48,117.25,128.67,131.35,131.62,139.88,150.31$, 158.22, 160.09. Anal. Calcd for $\mathrm{C}_{14} \mathrm{H}_{10} \mathrm{~N}_{4} \mathrm{O}$ : C, 67.2; H, 4.0; N, 22.4. Found: C, 67.5; H, 4.1; N, 22.5. $M=250,26$.

6-Amino-2-oxo-1-m-tolyl-1,2-dihydropyridine-3,5-dicarbonitrile (7Bc). Yield 78\%; pale yellow powder (from MeOH); mp 233-234 ${ }^{\circ} \mathrm{C}$. IR $(\mathrm{KBr}) \mathrm{cm}^{-1}: 3390,3301,3218\left(\mathrm{NH}_{2}\right), 2225$, $2213(\mathrm{C} \equiv \mathrm{N}), 1693(\mathrm{C}=\mathrm{O}) . \mathrm{LC} / \mathrm{MS}, m / z(\%): 249.0$ (100) [M-1] ${ }^{-1} \mathrm{H}$ NMR (500 MHz, DMSO-d $)$ $\delta 2.32\left(\mathrm{~s}, 3 \mathrm{H}, \mathrm{CH}_{3}\right), 6.89\left(\mathrm{~d}, J=7.3 \mathrm{~Hz}, 1 \mathrm{H}, \mathrm{H}_{\mathrm{Ar}}\right), 6.92\left(\mathrm{~s}, 1 \mathrm{H}, \mathrm{H}_{\mathrm{Ar}}\right), 7.19(\mathrm{~d}, J=7.3 \mathrm{~Hz}, 1 \mathrm{H}$, $\left.\mathrm{H}_{\mathrm{Ar}}\right), 7.35\left(\mathrm{t}, J=7.4 \mathrm{~Hz}, 1 \mathrm{H}, \mathrm{H}_{\mathrm{Ar}}\right), 7.63\left(\mathrm{~s}, 1 \mathrm{H}, \mathrm{C}^{4} \mathrm{H}\right)$, the signal of $\mathrm{NH}_{2}$ was not observed presumably due to the fast deutero-exchange. ${ }^{13} \mathrm{C}$ NMR (50 MHz, DMSO- $\left.d_{6}\right) \delta 21.28,78.25$, 79.94, 119.08, 119.57, 126.62, 129.64, 129.97, 130.09, 136.38, 139.68, 147.89, 158.45, 162.09. Anal. Calcd for $\mathrm{C}_{14} \mathrm{H}_{10} \mathrm{~N}_{4} \mathrm{O}$ : C, 67.7; H, 4.5; N, 22.8. Found: C, 67.2; H, 4.0; N, 22.4. $M=$ 250,26 .

6-Amino-1-(2-methoxyphenyl)-2-oxo-1,2-dihydropyridine-3,5-dicarbonitrile (7Bd). Yield $75 \%$; yellow powder (from $\mathrm{MeOH}) ; \mathrm{mp} 158-159{ }^{\circ} \mathrm{C}$. IR $(\mathrm{KBr}) \mathrm{cm}^{-1}: 3503,3312,3202\left(\mathrm{NH}_{2}\right)$, 2230, $2214(\mathrm{C} \equiv \mathrm{N}), 1671(\mathrm{C}=\mathrm{O}), 1639 . \mathrm{LC} / \mathrm{MS}, \mathrm{m} / z(\%): 264.8(100)[\mathrm{M}+1]^{+} .{ }^{1} \mathrm{H}$ NMR $(500$ MHz, DMSO-d $\left.d_{6}\right) \delta 3.78\left(\mathrm{~s}, 3 \mathrm{H}, \mathrm{CH}_{3}\right), 7.12\left(\mathrm{t}, J=7.5 \mathrm{~Hz}, 1 \mathrm{H}, \mathrm{H}_{\mathrm{Ar}}\right), 7.26\left(\mathrm{~d}, J=8.3 \mathrm{~Hz}, 1 \mathrm{H}, \mathrm{H}_{\mathrm{Ar}}\right)$, $7.29\left(\mathrm{~d}, J=7.5 \mathrm{~Hz}, 1 \mathrm{H}, \mathrm{H}_{\mathrm{Ar}}\right), 7.54\left(\mathrm{t}, J=7.9 \mathrm{~Hz}, 1 \mathrm{H}, \mathrm{H}_{\mathrm{Ar}}\right), 8.31\left(\mathrm{~s}, 1 \mathrm{H}, \mathrm{C}^{4} \mathrm{H}\right)$, the signal of $\mathrm{NH}_{2}$ was not observed presumably due to the fast deuteron-exchange. ${ }^{13} \mathrm{C}$ NMR $\left(50 \mathrm{MHz}, \mathrm{DMSO}-d_{6}\right)$ $\delta 56.69,74.32,87.21,114.20,116.67,117.30,122.25,122.66,130.47,132.23,150.32,155.48$, 158.31, 159.72. Anal. Calcd for $\mathrm{C}_{14} \mathrm{H}_{10} \mathrm{~N}_{4} \mathrm{O}_{2}$ : C, 63.2; H, 3.8; N, 21.0. Found: C, 63.6; H, 3.5; N, 21.3. $M=266,25$

6-Amino-1-(2-ethylphenyl)-2-oxo-1,2-dihydropyridine-3,5-dicarbonitrile (7Be). Yield 55\%; yellow powder (from AcOH); mp 220-225 ${ }^{\circ} \mathrm{C}$. IR (KBr) cm${ }^{-1}: 3450,3315,3270\left(\mathrm{NH}_{2}\right), 2220$, $2214(\mathrm{C} \equiv \mathrm{N}), 1695,1680(\mathrm{C}=\mathrm{O}) . \mathrm{LC} / \mathrm{MS}, \mathrm{m} / z(\%): 265.2(100)[\mathrm{M}+1]^{+} .{ }^{1} \mathrm{H}$ NMR $(500 \mathrm{MHz}$, DMSO-d $\left.d_{6}\right) \delta 1.08\left(\mathrm{t}, J=7.5 \mathrm{~Hz}, 3 \mathrm{H}, \mathrm{CH}_{2} \underline{\mathrm{CH}}_{3}\right), 2.28\left(\mathrm{q}, J=7.5 \mathrm{~Hz}, 2 \mathrm{H}, \underline{\mathrm{CH}_{2}} \mathrm{CH}_{3}\right), 7.22(\mathrm{~d}, J=$ $\left.7.7 \mathrm{~Hz}, 1 \mathrm{H}, \mathrm{H}_{\mathrm{Ar}}\right), 7.38\left(\mathrm{t}, J=5.6 \mathrm{~Hz}, 1 \mathrm{H}, \mathrm{H}_{\mathrm{Ar}}\right), 7.47\left(\mathrm{~d}, J=5.9 \mathrm{~Hz}, 1 \mathrm{H}, \mathrm{H}_{\mathrm{Ar}}\right), 7.49$ (t, $J=4.9 \mathrm{~Hz}$, $\left.1 \mathrm{H}, \mathrm{H}_{\mathrm{Ar}}\right), 7.93$ (br. s, $\left.2 \mathrm{H}, \mathrm{NH}_{2}\right), 8.31 \mathrm{~s}\left(1 \mathrm{H}, \mathrm{C}^{4} \mathrm{H}\right) .{ }^{13} \mathrm{C}$ NMR $\left(50 \mathrm{MHz}, \mathrm{DMSO}-d_{6}\right) \delta 14.17,23.73$, $74.35,87.83,116.74,117.14,128.55,129.30,130.56,130.96,132.73,141.79,150.53,158.08$, 159.82. Anal. Calcd for $\mathrm{C}_{15} \mathrm{H}_{12} \mathrm{~N}_{4} \mathrm{O}: \mathrm{C}, 68.2 ; \mathrm{H}, 4.6$; N, 21.2. Found: C, 68.3; H, 4.5; N, 21.4. $M$ $=264,28$.

6-Amino-1-(2-nitrophenyl)-2-oxo-1,2-dihydropyridine-3,5-dicarbonitrile (7Bf). Yield 61\%; pale brown powder (from DMF); mp 292-294 ${ }^{\circ} \mathrm{C}$. IR $(\mathrm{KBr}) \mathrm{cm}^{-1}: 3445,3280\left(\mathrm{NH}_{2}\right), 2235,2213$ 
$(\mathrm{C} \equiv \mathrm{N}), 1683(\mathrm{C}=\mathrm{O}) . \mathrm{LC} / \mathrm{MS}, m / z(\%): 280.0(100)[\mathrm{M}-1]^{-} .{ }^{1} \mathrm{H}$ NMR (500 MHz, DMSO- $\left.d_{6}\right) \delta$ $7.71\left(\mathrm{~d}, J=7.6 \mathrm{~Hz}, 1 \mathrm{H}, \mathrm{H}_{\mathrm{Ar}}\right), 7.83\left(\mathrm{t}, J=6.7 \mathrm{~Hz}, 1 \mathrm{H}, \mathrm{H}_{\mathrm{Ar}}\right), 7.97\left(\mathrm{t}, J=7.49 \mathrm{~Hz}, 1 \mathrm{H}, \mathrm{H}_{\mathrm{Ar}}\right), 8.32$ $\left(\mathrm{d}, J=8.0 \mathrm{~Hz}, 1 \mathrm{H}, \mathrm{H}_{\mathrm{Ar}}\right), 8.37\left(\mathrm{~s}, 1 \mathrm{H}, \mathrm{C}^{4} \mathrm{H}\right)$, the signal of $\mathrm{NH}_{2}$ was not observed presumably due to the fast deuteron-exchange. ${ }^{13} \mathrm{C}$ NMR $\left(50 \mathrm{MHz}, \mathrm{DMSO}-d_{6}\right) \delta 75.08,87.24,116.28,116.76$, $126.98,128.29,132.24,132.57,136.88,146.77,151.13,158.33,159.76$. Anal. Calcd for $\mathrm{C}_{13} \mathrm{H}_{7} \mathrm{~N}_{5} \mathrm{O}_{3}$ : C, 55.3; H, 2.9; N, 25.4. Found: C, 55.5; H, 2.5; N, 24.9. $M=281,23$.

6-Amino-1-(4-chlorophenyl)-2-oxo-1,2-dihydropyridine-3,5-dicarbonitrile (7Bg). Yield 30\%; pale yellow powder (from DMF); mp 298-299 ${ }^{\circ} \mathrm{C}$. IR (KBr) cm ${ }^{-1}: 3339\left(\mathrm{NH}_{2}\right), 2219$ $(\mathrm{C} \equiv \mathrm{N}), 1653(\mathrm{C}=\mathrm{O}) . \mathrm{LC} / \mathrm{MS}, m / z(\%): 270.0(100)[\mathrm{M}-1]^{-} .{ }^{1} \mathrm{H}$ NMR (500 MHz, DMSO-d $) \delta$ $7.41\left(\mathrm{~d}, J=6.8 \mathrm{~Hz}, 2 \mathrm{H}, \mathrm{H}_{\mathrm{Ar}}\right), 7.64\left(\mathrm{~d}, J=6.8 \mathrm{~Hz}, 2 \mathrm{H}, \mathrm{H}_{\mathrm{Ar}}\right), 7.94$ (br. s, $\left.\mathrm{NH}_{2}\right), 8.30\left(\mathrm{~s}, 1 \mathrm{H}, \mathrm{C}^{4} \mathrm{H}\right)$, the signal intensity of $\mathrm{NH}_{2}$ was lowered presumably due to the fast deuteron-exchange. ${ }^{13} \mathrm{C}$ NMR (50 MHz, DMSO-d6) $\delta$ 30.63, 73.63, 87.01, 115.91, 116.60, 130.39, 130.57, 132.78, 134.63, 149.94, 157.63, 159.46. Anal. Calcd for $\mathrm{C}_{13} \mathrm{H}_{7} \mathrm{ClN}_{4} \mathrm{O}$ : C, 57.7; H, 2.6; N, 20.7. Found: C, 57.5; H, 2.5; N, 20.9. $M=270,67$.

Ethyl 2-amino-5-cyano-6-oxo-1-phenyl-1,6-dihydropyridine-3-carboxylate (8Ca). Yield 53\%; yellow powder (from $\mathrm{BuOH}) ; \mathrm{mp} 168-170{ }^{\circ} \mathrm{C}$. IR $(\mathrm{KBr}) \mathrm{cm}^{-1}: 3351\left(\mathrm{NH}_{2}\right), 2220(\mathrm{C} \equiv \mathrm{N})$, 1691, $1656(\mathrm{C}=\mathrm{O})$. LC/MS, $m / z(\%): 284.0(100)[\mathrm{M}+1]^{+} .{ }^{1} \mathrm{H}$ NMR (500 MHz, DMSO-d 6$) \delta$ $1.18\left(\mathrm{t}, J=7.1 \mathrm{~Hz}, 3 \mathrm{H}, \mathrm{CH}_{2} \underline{\mathrm{CH}}_{3}\right), 4.06$ (q, $\left.J=7.1 \mathrm{~Hz}, 2 \mathrm{H}, \underline{\mathrm{CH}_{2}} \mathrm{CH}_{3}\right), 6.96$ (t, $J=7.6 \mathrm{~Hz}, 1 \mathrm{H}$, $\left.\mathrm{H}_{\mathrm{Ar}}\right), 7.23\left(\mathrm{t}, J=7.9 \mathrm{~Hz}, 2 \mathrm{H}, \mathrm{H}_{\mathrm{Ar}}\right), 7.58\left(\mathrm{~d}, J=7.6 \mathrm{~Hz}, 2 \mathrm{H}, \mathrm{H}_{\mathrm{Ar}}\right), 8.10\left(\mathrm{~s}, 1 \mathrm{H}, \mathrm{C}^{4} \mathrm{H}\right), 8.64$ (br. s, $\mathrm{NH}_{2}$ ), the signal intensity of $\mathrm{NH}_{2}$ was lowered presumably due to the fast deuteron-exchange. ${ }^{13} \mathrm{C}$ NMR $\left(50 \mathrm{MHz}, \mathrm{DMSO}-d_{6}\right) \delta 14.74,60.32,83.55,92.31,118.93,129.05,129.09,129.50$, 130.08, 130.08, 136.42, 147.26, 158.60, 161.45, 165.87. Anal. Calcd for $\mathrm{C}_{15} \mathrm{H}_{13} \mathrm{~N}_{3} \mathrm{O}_{3}$ : $\mathrm{C}, 63.6 ; \mathrm{H}$, 4.6; N, 14.8. Found: C, 63.8; H, 4.8; N, 14.9. $M=283,28$.

Ethyl 2-amino-5-cyano-6-oxo-1-p-tolyl-1,6-dihydropyridine-3-carboxylate (8Cb). Yield $62 \%$; pale brown powder (from $\mathrm{BuOH}$ ); mp 125-128 ${ }^{\circ} \mathrm{C}$. IR $(\mathrm{KBr}) \mathrm{cm}^{-1}: 3480\left(\mathrm{NH}_{2}\right), 2210$ $(\mathrm{C} \equiv \mathrm{N}), 1646(\mathrm{C}=\mathrm{O}) . \mathrm{LC} / \mathrm{MS}, m / z(\%): 298.0(100)[\mathrm{M}+1]^{+} .{ }^{1} \mathrm{H}$ NMR (500 MHz, DMSO- $\left.d_{6}\right) \delta$ 1.19 (t, $\left.J=7.1 \mathrm{~Hz}, 3 \mathrm{H}, \mathrm{CH}_{2} \underline{\mathrm{CH}_{3}}\right), 2.26$ (s, 3H, $\left.\underline{\mathrm{CH}_{3}} \mathrm{Ar}\right), 4.07$ (q, $\left.J=7.1 \mathrm{~Hz}, 2 \mathrm{H}, \underline{\mathrm{CH}_{2}} \mathrm{CH}_{3}\right), 7.14$ $\left(\mathrm{d}, J=8.2 \mathrm{~Hz}, 2 \mathrm{H}, \mathrm{H}_{\mathrm{Ar}}\right), 7.43\left(\mathrm{~d}, J=8.2 \mathrm{~Hz}, 2 \mathrm{H}, \mathrm{H}_{\mathrm{Ar}}\right), 8.62\left(\mathrm{~s}, 1 \mathrm{H}, \mathrm{C}^{4} \mathrm{H}\right) 10.20\left(\mathrm{~s}, \mathrm{NH}_{2}\right)$, the signal intensity of $\mathrm{NH}_{2}$ was lowered presumably due to the fast deuteron-exchange. ${ }^{13} \mathrm{C}$ NMR (50 MHz, DMSO-d6) $\delta 15.47,20.98,57.76,59.33,59.66,119.91,120.83,129.38,131.84$, 137.89, 148.87, 149.80, 150.86, 164.78, 167.60, 183.96. Anal. Calcd for $\mathrm{C}_{16} \mathrm{H}_{15} \mathrm{~N}_{3} \mathrm{O}_{3}$ : C, 64.5; $\mathrm{H}$, 5.1; N, 14.1. Found: C, 63.8; H, 5.7; N, 14.9. $M=297,31$.

Ethyl 2-amino-5-cyano-6-oxo-1-m-tolyl-1,6-dihydropyridine-3-carboxylate (8Cc). Yield 65\%; yellow powder (from MeOH); mp 154-155 ${ }^{\circ} \mathrm{C}$. IR $(\mathrm{KBr}) \mathrm{cm}^{-1}: 3378\left(\mathrm{NH}_{2}\right), 2205(\mathrm{C} \equiv \mathrm{N})$, 1684, 1650 (C=O). LC/MS, m/z (\%): 296.0 (100) [M-1] . ${ }^{1} \mathrm{H}$ NMR (500 MHz, DMSO-d6) $\delta 1.17$ $\left(\mathrm{t}, J=7.1 \mathrm{~Hz}, 3 \mathrm{H}, \mathrm{CH}_{2} \underline{\mathrm{CH}}_{3}\right), 2.24\left(\mathrm{~s}, 3 \mathrm{H}, \mathrm{ArCH}_{3}\right), 4.05\left(\mathrm{q}, J=7.1 \mathrm{~Hz}, 2 \mathrm{H}, \underline{\mathrm{CH}_{2}} \mathrm{CH}_{3}\right), 6.78(\mathrm{~d}, J=$ $\left.7.2 \mathrm{~Hz}, 1 \mathrm{H}, \mathrm{H}_{\mathrm{Ar}}\right), 7.11\left(\mathrm{t}, J=7.8 \mathrm{~Hz}, 1 \mathrm{H}, \mathrm{H}_{\mathrm{Ar}}\right), 7.37\left(\mathrm{~d}, J=7.8 \mathrm{~Hz}, 1 \mathrm{H}, \mathrm{H}_{\mathrm{Ar}}\right), 7.41\left(\mathrm{~s}, 1 \mathrm{H}, \mathrm{H}_{\mathrm{Ar}}\right)$, $8.08\left(\mathrm{~s}, 1 \mathrm{H}, \mathrm{C}^{4} \mathrm{H}\right), 8.56\left(\mathrm{~s}, \mathrm{NH}_{2}\right)$, the signal intensity of $\mathrm{NH}_{2}$ was lowered presumably due to the fast deuteron-exchange. ${ }^{13} \mathrm{C} \mathrm{NMR}\left(50 \mathrm{MHz}, \mathrm{DMSO}-d_{6}\right) \delta 14.74,21.44,61.26,88.02,90.95$, 
117.52, 126.12, 129.53, 130.79, 134.29, 140.73, 148.46, 157.79, 160.26, 165.90. Anal. Calcd for $\mathrm{C}_{16} \mathrm{H}_{15} \mathrm{~N}_{3} \mathrm{O}_{3}$ : C, 64.6; H, 5.1; N, 14.1. Found: C, 63.8; H, 4.9; N, 14.6. $M=297,31$.

Ethyl 2-amino-5-cyano-1-(2-methoxyphenyl)-6-oxo-1,6-dihydropyridine-3-carboxylate (8Cd). Yield 55\%; pale yellow powder (from $\mathrm{BuOH}) ; \mathrm{mp} 180-183{ }^{\circ} \mathrm{C}$. IR (KBr) $\mathrm{cm}^{-1}: 3567$, 3481, $3391\left(\mathrm{NH}_{2}\right), 2216(\mathrm{C} \equiv \mathrm{N}), 1673,1631(\mathrm{C}=\mathrm{O})$. LC/MS, $m / z(\%): 314.0(100)[\mathrm{M}+1]^{+} .{ }^{1} \mathrm{H}$ NMR (500 MHz, DMSO-d $\left.d_{6}\right) 1.18\left(\mathrm{t}, J=6.9 \mathrm{~Hz}, 3 \mathrm{H}, \mathrm{CH}_{2} \underline{\mathrm{CH}}_{3}\right), 3.85$ (s, 3H, $\left.\mathrm{OCH}_{3}\right), 4.06$ (q, $J$ $\left.=6.9 \mathrm{~Hz}, 2 \mathrm{H}, \underline{\mathrm{CH}_{2}} \mathrm{CH}_{3}\right), 6.88\left(\mathrm{t}, J=7.4 \mathrm{~Hz}, 1 \mathrm{H}, \mathrm{H}_{\mathrm{Ar}}\right), 6.96\left(\mathrm{t}, J=7.9 \mathrm{~Hz}, 1 \mathrm{H}, \mathrm{H}_{\mathrm{Ar}}\right), 7.02(\mathrm{~d}, J=$ $\left.7.9 \mathrm{~Hz}, 1 \mathrm{H}, \mathrm{H}_{\mathrm{Ar}}\right), 8.13\left(\mathrm{~s}, 1 \mathrm{H}, \mathrm{C}^{4} \mathrm{H}\right), 8.21$ (br s, $\left.\mathrm{NH}_{2}\right), 8.25\left(\mathrm{~d}, J=7.8 \mathrm{~Hz}, 1 \mathrm{H}, \mathrm{H}_{\mathrm{Ar}}\right)$, the signal intensity of $\mathrm{NH}_{2}$ was lowered presumably due to the fast deuteron-exchange. ${ }^{13} \mathrm{C} \mathrm{NMR}(50 \mathrm{MHz}$, DMSO- $\left.d_{6}\right) \delta 15.10,56.53,59.58,72.78,75.14,111.12,118.89,118.99,120.16,121.07,123.05$, 128.82, 148.09, 149.22, 163.65, 167.22. Anal. Calcd for $\mathrm{C}_{16} \mathrm{H}_{15} \mathrm{~N}_{3} \mathrm{O}_{4}$ : C, 61.3; H, 4.8; N, 13.4. Found: C, 61.7; H, 4.8; N, 13.8. $M=313,31$.

Ethyl 2-amino-5-cyano-1-(2-ethylphenyl)-6-oxo-1,6-dihydropyridine-3-carboxylate (8Ce). Yield 68\%; yellow powder (from DMF); mp 163-165 ${ }^{\circ} \mathrm{C}$. IR (KBr) cm ${ }^{-1}: 3495,3465,3421$ $\left(\mathrm{NH}_{2}\right), 2205(\mathrm{C} \equiv \mathrm{N}), 1680,1645(\mathrm{C}=\mathrm{O}) . \mathrm{LC} / \mathrm{MS}, \mathrm{m} / z(\%): 312.0(100)[\mathrm{M}+1]^{+} .{ }^{1} \mathrm{H}$ NMR $(500$ $\left.\mathrm{MHz}, \mathrm{DMSO}-d_{6}\right) \delta 1.14\left(\mathrm{t}, J=7.6 \mathrm{~Hz}, 3 \mathrm{H}, \mathrm{CH}_{2} \underline{\mathrm{CH}_{3}}\right), 1.18\left(\mathrm{t}, J=7.1 \mathrm{~Hz}, 3 \mathrm{H}, \mathrm{OCH}_{2} \underline{\mathrm{CH}}_{3}\right), 2.55$ (q, $\left.J=6.9 \mathrm{~Hz}, 2 \mathrm{H}, \underline{\mathrm{CH}_{2}} \mathrm{CH}_{3}\right), 4.05\left(\mathrm{q}, J=7.1 \mathrm{~Hz}, 2 \mathrm{H}, \mathrm{OCH}_{2} \mathrm{CH}_{3}\right), 7.04\left(\mathrm{t}, J=7.4 \mathrm{~Hz}, 1 \mathrm{H}, \mathrm{H}_{\mathrm{Ar}}\right)$, $7.13\left(\mathrm{t}, J=7.6 \mathrm{~Hz}, 1 \mathrm{H}, \mathrm{H}_{\mathrm{Ar}}\right), 7.18\left(\mathrm{~d}, J=7.5 \mathrm{~Hz}, 1 \mathrm{H}, \mathrm{H}_{\mathrm{Ar}}\right), 7.66\left(\mathrm{~d}, J=8.0 \mathrm{~Hz}, 1 \mathrm{H}, \mathrm{H}_{\mathrm{Ar}}\right), 8.09$ (s, $\left.1 \mathrm{H}, \mathrm{C}^{4} \mathrm{H}\right), 8.10\left(\mathrm{~s}, \mathrm{NH}_{2}\right)$, the signal intensity of $\mathrm{NH}_{2}$ was lowered presumably due to the fast deuteron-exchange. ${ }^{13} \mathrm{C}$ NMR (50 MHz, DMSO-d6) $\delta 14.42,15.15,24.52,59.52,72.45,75.77$, 119.24, 120.35, 123.84, 124.52, 126.51, 128.98, 135.69, 137.39, 149.55, 164.61, 167.56. Anal. Calcd for $\mathrm{C}_{17} \mathrm{H}_{17} \mathrm{~N}_{3} \mathrm{O}_{3}$ : C, 65.6; H, 5.5; N, 13.5. Found: C, 65.8; H, 5.8; N, 13.9. $M=311,34$.

Ethyl 2-amino-5-cyano-1-(2-nitrophenyl)-6-oxo-1,6-dihydropyridine-3-carboxylate (8Cf). Yield 60\%; yellow crystals (from DMF); mp 237-238 ${ }^{\circ} \mathrm{C}$. IR $(\mathrm{KBr}) \mathrm{cm}^{-1}: 3379,3286\left(\mathrm{NH}_{2}\right)$, $2207(\mathrm{C} \equiv \mathrm{N}), 1694,1650(\mathrm{C}=\mathrm{O}) . \mathrm{LC} / \mathrm{MS}, \mathrm{m} / z(\%): 329.0(100)[\mathrm{M}+1]^{+} .{ }^{1} \mathrm{H} \mathrm{NMR}(500 \mathrm{MHz}$, DMSO-d $\left.d_{6}\right) \delta 1.19\left(\mathrm{t}, J=7.1 \mathrm{~Hz}, 3 \mathrm{H}, \mathrm{CH}_{2} \underline{\mathrm{CH}}_{3}\right), 4.08\left(\mathrm{q}, J=7.1 \mathrm{~Hz}, 2 \mathrm{H}, \underline{\mathrm{CH}_{2}} \mathrm{CH}_{3}\right), 7.19(\mathrm{t}, J=$ $\left.7.3 \mathrm{~Hz}, 1 \mathrm{H}, \mathrm{H}_{\mathrm{Ar}}\right), 7.69\left(\mathrm{t}, J=7.3 \mathrm{~Hz}, 1 \mathrm{H}, \mathrm{H}_{\mathrm{Ar}}\right), 8.12\left(\mathrm{~d}, J=7.1 \mathrm{~Hz}, 1 \mathrm{H}, \mathrm{H}_{\mathrm{Ar}}\right), 8.15\left(\mathrm{~s}, 1 \mathrm{H}, \mathrm{C}^{4} \mathrm{H}\right)$, $8.54\left(\mathrm{~d}, J=8.4 \mathrm{~Hz}, 1 \mathrm{H}, \mathrm{H}_{\mathrm{Ar}}\right), 10.39\left(\mathrm{~s}, \mathrm{NH}_{2}\right)$, the signal intensity of $\mathrm{NH}_{2}$ was lowered presumably due to the fast deuteron-exchange. ${ }^{13} \mathrm{C}$ NMR $\left(50 \mathrm{MHz}, \mathrm{DMSO}-d_{6}\right) \delta 14.64,60.98$, 85.32, 91.88, 117.63, 126.65, 128.81, 131.95, 132.24, 136.54, 146.69, 148.72, 157.79, 160.31, 165.59. Anal. Calcd for $\mathrm{C}_{15} \mathrm{H}_{12} \mathrm{~N}_{4} \mathrm{O}_{5}$ : C, 54.9; H, 3.7; N, 17.1. Found: C, 54.8; H, 4.1; N, 17.5. $M$ $=328,28$.

Ethyl 2-amino-1-(4-chlorophenyl)-5-cyano-6-oxo-1,6-dihydropyridine-3-carboxylate (8Cg). Yield 74\%; yellow crystals (from DMF); mp 245-247 ${ }^{\circ} \mathrm{C}$. IR $(\mathrm{KBr}) \mathrm{cm}^{-1}: 3319,3188\left(\mathrm{NH}_{2}\right)$, $2225(\mathrm{C} \equiv \mathrm{N}), 1693,1667(\mathrm{C}=\mathrm{O})$. LC/MS, $m / z(\%): 317.0(100)[\mathrm{M}-1]^{+} .{ }^{1} \mathrm{H}$ NMR (500 MHz, DMSO-d $\left.d_{6}\right) \delta 1.31\left(\mathrm{t}, J=7.1, \mathrm{~Hz}, 3 \mathrm{H}, \mathrm{CH}_{2} \underline{\mathrm{CH}}_{3}\right), 4.26$ (q, $\left.J=7.1 \mathrm{~Hz}, 2 \mathrm{H}, \underline{\mathrm{CH}_{2}} \mathrm{CH}_{3}\right), 7.44(\mathrm{~m}, 2 \mathrm{H}$, $\left.\mathrm{H}_{\mathrm{Ar}}\right), 7.67\left(\mathrm{~m}, 2 \mathrm{H}, \mathrm{H}_{\mathrm{Ar}}\right), 8.38\left(\mathrm{~s}, 1 \mathrm{H}, \mathrm{C}^{4} \mathrm{H}\right), 8.91$ (br. $\left.\mathrm{s}, \mathrm{NH}_{2}\right)$, the signal intensity of $\mathrm{NH}_{2}$ was lowered presumably due to the fast deuteron-exchange. ${ }^{13} \mathrm{C}$ NMR $\left(50 \mathrm{MHz}, \mathrm{DMSO}-d_{6}\right) \delta 14.08$, $60.56,86.72$, 90.31, 117.01, 130.43, 130.70, 132.77, 134.60, 147.89, 157.12, 159.72, 165.21. 
Anal. Calcd for $\mathrm{C}_{15} \mathrm{H}_{12} \mathrm{ClN}_{3} \mathrm{O}_{3}$ : C, 56.7; H, 3.8; N, 13.2. Found: C, 56.9; H, 3.6; N, 13.1. $M=$ 317.73.

\section{Acknowledgements}

Authors are grateful to Enamine Ltd (Kiev, Ukraine) for the opportunity to perform a part of this work by Valeriya P. Tkachova in the company laboratories.

\section{References}

1. See for review: Henry, G. D. Tetrahedron 2004, 60, 6043.

2. See for review: (a) Torres, M.; Gil, S.; Parra, M. Curr. Org. Chem. 2005, 9, 1757. (b) Pemberton, N.; Chorell, E.; Almqvist, F. Top. Heterocycl. Chem. 2006, $1,1$.

3. Gadekar, S. M. DE Patent 2,555,411, 1976; Chem. Abstr. 1976, 85, 198163 b.

4. See, for example, reviews: Dosanjh, A. Transplantation Proc. 2007, 39, 2153. (b) Dosanjh, A. Eur. J. Pharmacol. 2006, 536, 219.

5. (a) Jochmans, D.; Deval, J.; Kesteleyn, B.; Marck, H.V.; Bettens, E.; De Baere, I.; Dehertogh, P.; Ivens, T.; Van Ginderen, M.; Van Schoubroeck, B.; Ehteshami, M.;Wigerinck, P.; Götte, M.; Hertogs, K. J. Virology 2006, 80(24), 12283. (b) Ehteshami, M.; Scarth, B. J.; Tchesnokov E. P.; Dash, C.; Le Grice, S. F. J.; Hallenberger, S.; Jochmans, D.; Götte, M. J. Bio. Chem. 2008, 283(44), 29904.

6. (a) Kesteleyn, B. R. R.; Van De Vreken, W.; Kindermans, N. M. F.; Canard, M. F. J.-M. G.; Hertogs, K.; Bettens, E.; De Vroey, V. C. P.; Jochmans, D. E. D.; Wigerinck, P. T. B. P.; Wang, J.; Tahri, A.; Surleraux, D. L. N. G. Int. Patent WO 2005110411; Chem. Abstr. 2005, 143, 477858. (b) Jochmans, D. E. D.; Wigerinck, P. T. B. P. Int. Patent WO 2007088214; Chem. Abstr. 2007, 147, 227136.

7. For recent review on application of milrinone in heart failure treatment, see: (a) Shin, D. D.; Brandimarte, F.; De Luca, L.; Sabbah, H. N.; Fonarow, G. C.; Filippatos, G.; Komajda, M.; Gheorghiade, M. Am. J. Cardiol. 2007, 99(2A), 4A.

8. Examples of studies of milrinone analogs: (a) Lo Presti, E.; Boggia, R.; Feltrin, A.; Menozzi, G.; Dorigo, P.; Mosti, L. Farmaco 1999, 54(7), 465. (b) Cody, V.; Wojtczak, A.; Davis, F. B.; Davis, P. J.; Blas, S. D. J. Med. Chem. 1995, 38 (11), 1990. (c) Robert, N.; Verrier, C.; Hoarau, C.; Celanire, S.; Marsais, F. Arkivoc 2008, (vii), 92.

9. Ferraz, A. C.; Angelucci, M. E. M.; Da Costa, M. L.; Batista, I. R.; De Olivera, B. H.; Da Cunha, C. Pharmacol. Biochem. Behavior 1999, 63, 367.

10. (a) Dyachenko, V. D.; Tkachev, R. P. Russ. J. Org. Chem. 2002, 38(5), 731. Translated from Zh. Obshch. Khim. 2002, 38 (5), 768. (b) Dyachenko, V. D.; Tkachev, R. P.; Chernega, 
A. N. Chem. Heterocycl. Compd. 2005, 41(4), 503. Translated from Khim. Geterotsikl. Soed. 2005, 4, 589.

11. (a) Dyachenko, V. D.; Tkachev, R. P. Russ. J. Org. Chem. 2003, 39, 1174. Translated from Zh. Org. Khim. 2003, 39, 1245. (b) Tkachev, R. P.; Bityukova, O. S.; Dyachenko, V. D.; Tkacheva, V. P.; Dyachenko, A. D. Russ. J. Gen. Chem. 2007, 77, 116. Translated from Zh. Obshch. Khim. 2007, 77, 125.

12. See for review: (a) Dyachenko, V. D.; Tkachev, R. P. Russ. J. Org. Chem. 2003, 39, 757. Translated from Zh. Org. Khim. 2003, 39, 807. (b) Dyachenko, V. D.; Tkachev, R. P. Russ. J. Org. Chem. 2006, 42, 149. Translated from Zh. Org. Khim. 2006, 42, 167.

13. Wang K.; Nguyen K.; Huang Y.; Domling A. J. Comb. Chem. 2009, 11, 920.

14. (a) Gorobets, N. Yu.; Yousefi, B. H.; Belaj, F.; Kappe, C. O. Tetrahedron 2004, 60, 8633. (b) Yermolayev, S. A.; Gorobets, N. Yu.; Lukinova, E. V.; Shishkin, O. V.; Shishkina, S. V.; Desenko, S. M. Tetrahedron 2008, 64, 4649. (c) Yermolayev, S. A.; Gorobets, N. Yu.; Desenko, S. M. J. Comb. Chem. 2009, 11 (1), 44. (d) Gorobets, N. Yu.; Sedash, Yu. V.; Shishkina, S. V.; Shishkin, O. V.; Yermolayev, S. A.; Desenko, S. M. Arkivoc. 2009, (xiii), 23. (e) Dawood, K. M.; Farag, A. M.; Khedr, N. A. Arkivoc 2008, (xv), 166.

15. Tkachova V. P.; Gorobets N. Yu; Tkachov R. P.; Dyachenko O. D.; Rusanov E. B.; Dyachenko V. D. Arkivoc 2010, (xi), 254.

16. Compounds $\mathbf{8 C a - C g}$ are novel, however, similar N1-usubstituted derivatives has been described earlier using different strategy: Cocco M.T.; Congiu C.; Maccioni A. J. Heterocycl. Chem. 1989, 26, 1859.

17. (a) Eilbracht, P.; Balss, E.; Acker, M. Chem. Ber. 1985, 118 (2), 825. (b) Jimonet P.; Ribeill Y.; Bohme G. A.; Boireau A.; Chevé M.; Damour D.; Doblev A.; Genevois-Borella A.; Herman F.; Imperato A.; Le Guern S.; Manfré F.; Pratt J.; Randle J. C. R.; Stutzmann J-M.; Mignani S. J. Med. Chem. 2000, 43, 2371. (c) El Batran S. A.; Osman A. E. N.; Ismail M. M.; El Sayed A. M. Inflammopharmacology 2006, 14, 62.

18. (a) Sharanin Yu. A.; Shestopalov A. M.; Mortikov V. Yu.; Melenchuk S. N.; Promonenkov V. K.; Zolotarev B. M.; Litvinov V. P. Russ. Chem. Bull. 1986, 35 (1), 139. Translated from Izv. Akad. Nauk SSSR, Ser. Khim. 1986, 1, 153. (b) Dyachenko V. D.; Mitroshin A. E.; Litvinov V. P. Chem. Heterocl. Comp. 1996, 32 (9), 1058. Translated from Khim. Geterotsikl. Soed. 1996, 9, 1235. (c) Krivokolysko S. G.; Dyachenko V. D.; Litvinov V. P. Chem. Heterocl. Comp. 1998, 34 (10), 1174. Translated from Khim. Geterotsikl. Soed. 1998, 10, 1381. (d) Ismail M. M. F.; Noaman E. Med. Chem. Res. 2005, 14 (3), 382. (e) Ammar Y. A.; Ismail M. M. F.; El-Sehrawi H. M.; Noaman E.; Bayomi A. H.; Shawer T. Z. Arch. Pharm. 2006, 339 (8), 429. (f) Khalifa M. A. E.; Tammam G. H.; Elbanany A. A. A. Arch. Pharm. 1983, 316 (10), 822. (g) Mohareb R. M.; Hob J. H.; Alfarouka F. O. J. Chin. Chem. Soc. (Taipei, Taiwan). 2007, 54 (4), 1053. (h) Mohareb R. M.; Ho J. Z.; Mohamed A. A. Phosphorus, Sulfur, and Silicon 2007, 182, 1661. 
19. For a recent review on chemistry of cyanoacetanilides see: Dyachenko, V. D.; Tkachev, R. P.; Bityukova, O. S. Russ. J. Org. Chem. 2008, 44, 1565. Translated from Zh. Org. Khim. 2008, 44, 1591. 